\title{
Corrigendum: PARP3 is a promoter of chromosomal rearrangements and limits G4 DNA
}

Tovah A. Day, Jacob V. Layer, J. Patrick Cleary, Srijoy Guha, Kristen E. Stevenson, Trevor Tivey, Sunhee Kim, Anna C. Schinzel, Francesca Izzo, John Doench, David E. Root, William C. Hahn, Brendan D. Price

$\&$ David M. Weinstock

Nature Communications 8:15110 doi: 10.1038/ncomms15110 (2017); Published 27 Apr 2017; Updated 13 Jun 2017

In this Article, the antibody 'BG4' is consistently referred to incorrectly as 'hf2'. These errors appear in the Results and Methods. Additionally, the Article incorrectly cites reference 52 in the sentences 'A recent study described hf2, an engineered single-chain antibody specific for G4 DNA ${ }^{52}$ ' and 'pSANG10-3F-BG4 (Addgene 55756) ${ }^{52}$ was transformed into....' The correct citation is given below.

Biffi, G., Tannahill, D., McCafferty, J. \& Balasubramanian, S. Quantitative visualization of DNA G-quadruplex structures in human cells. Nat. Chem. 5, 182-186 (2013).

Open Access This article is licensed under a Creative Commons Attribution 4.0 International License, which permits use, sharing, adaptation, distribution and reproduction in any medium or format, as long as you give appropriate credit to the original author(s) and the source, provide a link to the Creative Commons
license, and indicate if changes were made. The images or other third party material in this article are included in the article's Creative Commons license, unless indicated otherwise in a credit line to the material. If material is not included in the article's Creative Commons license and your intended use is not permitted by statutory regulation or exceeds the permitted use, you will need to obtain permission directly from the copyright holder. To view a copy of this license, visit http://creativecommons.org/licenses/by/4.0/

(C) The Author(s) 2017 